2015-06

\title{
Lost and hound: The more-than-human networks of rural policing
}

\author{
Yarwood, Richard
}

http://hdl.handle.net/10026.1/3966

10.1016/j.jrurstud.2014.11.005

Journal of Rural Studies

Elsevier BV

All content in PEARL is protected by copyright law. Author manuscripts are made available in accordance with publisher policies. Please cite only the published version using the details provided on the item record or document. In the absence of an open licence (e.g. Creative Commons), permissions for further reuse of content should be sought from the publisher or author. 


\section{Lost and Hound:}

\section{The Hybrid Networks of Rural Policing, Missing People and Dogs}

\section{Abstract}

This paper advocates that a better understanding of rural policing can be gained if it is understood as a relational network. To illustrate the value of this approach, the paper considers the empirical example of dogs that are deployed by the police to search for missing people in rural terrain. In doing so it highlights that policing is not only concerned with preventing crime but also has a broader remit that is concerned with the well-being, safety and rights of citizens. Through a focus on search dogs, attention is given to the ways that non-human agencies are enrolled into policing networks. This not only broadens understanding of policing but also contributes to wider debates in rural studies about the place of animals, and especially working dogs, in the countryside. The paper provides critical insights into the idea of community policing and reveals much about the voluntary sector in rural places and the darker ruralities of missing people.

\section{Introduction}

This paper uses the opportunity afforded by this special issue to argue that discourses of 'community', widely deployed by the police and academics, can be problematic when describing policing in the countryside. Instead, it advocates that a better understanding of rural policing can be gained if it is understood as a relational network (Murdoch, 2000, 2006). This entails a consideration of the ways in which 
different practices, performances, agencies, knowledges and technologies are enrolled to produce varied, hybrid assemblages of 'rural policing' that manifest themselves in different places, forms and circumstances. Policing might be thought of as a series of 'encounters' that occur in particular spaces but are connected wider networks and spaces beyond it (Closs Stephens and Squire, 2012).To illustrate the value of this approach, the paper considers the empirical example of dogs that are deployed by the police to search for missing people in rural terrain.

The focus on search dogs is of interest for two reasons. First, it highlights that policing is not only concerned with preventing crime but also has a broader remit that is concerned with the well-being, safety and rights of citizens (Yarwood, 2007b).

Often a focus on crime and crime prevention has meant that these wider aspects of policing have been neglected although they remain an important staple of rural policing. Second, through a focus on search dogs, attention is given to the ways that non-human agencies are enrolled into policing networks. This not only broadens understanding of policing but also contributes to wider debates in rural studies about the place of animals in the countryside (Buller, 2014; Jones, 2003; Sellick and Yarwood, 2013; Urbanik, 2012).

This is a paper of two halves. The first half uses existing literature to critique ideas of community policing and consider the value of relational approaches in the study of rural policing. The second half uses these concepts, together with ideas from animal geographies, to develop a more-than-human understanding of civilian search dogs in searches for missing people.

\section{Beyond community policing}


'Community-based' has become something of a buzz-word in the policing of rural areas in Western countries. In response to increasingly centralised policing strategies, budgetary constraints and public pressure for more visible forms of policing, many police forces have taken measures to work in partnership with local communities to reduce crime, improve security and reduce the fear of crime in rural areas (Gilling, 2011; Mawby and Yarwood, 2011; Yarwood, 2008; Young, 1993). The intention is that voluntary, state and private agencies should work in partnership with the police in particular localities to identify and resolve crime and safety issues affecting them. Examples have included the establishment of Neighbourhood Watch schemes (Yarwood and Edwards, 1995); the development of village-based crime and safety partnerships (Small, 2001; Yarwood, 2007a; Yarwood, 2010a); the deployment of residents' patrols (Thurman and McGarrell, 2005); greater use of unsworn police officers (for example aboriginal officers, neighbourhood wardens and Police Community Support Officers (PCSOs)) from local communities (Cunneen, 2001; Fyfe, 1995) and the re-skilling of police officers to work more closely with rural communities (Smith, 2010). There may also be efforts to police areas in ways that are sympathetic to local cultures or viewpoints by, for example, working in partnership with community leaders or minority groups. Community policing is not, however, a panacea for rural policing and may be critiqued for three reasons.

\subsection{Community and Exclusion}

The idea of community is exclusionary as, by definition, it is necessary exclude as well as include when defining it (Staeheli, 2008). Those more likely to participate in community partnerships are usually drawn from elite groups of people 
that are more willing to work with the police to defend class interests (Herbert, 2006). Rural policing may revolve around a vision of rurality and community that reflects a hegemonic, idealised view of crime-free rural life (Yarwood, 2005; Yarwood and Gardner, 2000). More often than not, these visions tend to exclude on a cultural rather than a criminal basis. Certain groups, such as young people (Yarwood and Gardner, 2000), travellers or ethnic minorities (Vanderbeck, 2003), are more likely to be the target of community-based initiatives rather than included within in them (Gilling, 2011; Yarwood, 2010a). Rather than one rural community, there are many; raising questions about whether policing is for or of particular communities.

By contrast, some offences may be missed. The idea of community, with its emphasis on public, communal participation, has meant that community policing initiatives have tended to focus on public space. Domestic violence and crimes against women, which remain largely hidden in rural places (Liepins, 2000; Panelli et al., 2002; Websdale and Johnson, 1997), will remain neglected by initiatives only targeting public space.

Inclusion can also be problematic. Evidence has emerged that police officers who live and work in particular communities find it difficult to reconcile their 'insider' status with a need to police the people of that locality. Mouhanna (2011) recounts how French gendarmes' impartiality could be compromised by local friendships and gifts from the local populace. Some community-based officers may be reluctant to prosecute neighbours and friends for some offences such as drink-driving, delegating instead these duties to colleagues from outside their locality (Yarwood, 2011b). Malcom Young's (1993) account of policing in rural areas of the West Mercia Constabulary in the UK revealed high cultural expectations of the police and pressure for offices to respond to trivial, non-criminal concerns in their communities. 


\subsection{Governance through community}

Community policing usually refers to the efforts of various state, voluntary and private agencies to police particular places in partnership with each other. The term community, as various commentators have suggested (Herbert-Cheshire, 2000; Lockie et al., 2006; Woods, 2006), is something of a misnomer aimed, in part, at enrolling local people into taking responsibility for policing themselves (Thurman and McGarrell, 2005). Sometimes, as in the case of the UK's 1998 Crime and Disorder Act (Gilling, 2011), community-based policing has been driven by legislation that requires local agencies to work together. In other cases, co-operation has been encouraged through the use of grants or funds. Western Australia's Community Safety and Crime Prevention programme, for example, used a series of financial and collaborative incentives to encourage shire councils to adopt community-based approaches to crime prevention (Anderson and Tressider, 2008).

Even when initiatives have been driven from the 'bottom up', these tend to become incorporated into frameworks of national policy. Thus, residents' patrols started in New Zealand on an ad-hoc basis to patrol rural communities have become more formalised through the establishment of an umbrella body, Community Patrols of New Zealand (CPNZ), that has signed a memorandum of agreement with New Zealand Police. This, amongst other things, requires volunteers to undergo formal training and be vetted by the police. Similarly, Street Pastors are Christian volunteers that patrol the night time economy of the UK to ensure that safety of people on a night out (Middleton and Yarwood, 2013). Whilst originating in urban areas, many patrols now work in partnership with police forces in rural towns to agree patrol 
routes, respond to requests for help, share radio networks and ensure that all their members undertake formal training.

While both of these examples rely on volunteers, some rural policing partnerships have started to pay private security guards to undertake patrols. The 'Safer North Devon Community Safety Partnership', for example, has paid door staff (bouncers) to patrol as 'Street Marshals' in Bideford, a rural a market town, on Saturday nights to prevent anti-social behaviour and alcohol related crime.

Community policing reproduces a view that communities are the cause and solution of social problems (Lockie et al., 2006). Active citizenship, in the form of voluntary action in specific places, has been encouraged through policy-measures as a way of engaging local people with crime and safety in their locality (Yarwood, 2014). Some communities are more willing and able to help themselves and it is an irony that those in the need of most help are unlikely to benefit from self-help initiatives. The 'trapdoor of community', as Herbert (2005) puts it, means that many people unable or unwilling to work in formal partnership fall past the opportunities they offer. Far from empowering local people, many community-bases schemes represent a form of government from a distance (Higgins and Lockie, 2002) in which local people are judged as having 'succeeded or failed as citizens as a place-based community, with repercussions for the further treatment of that locality by the state (Desforges et al., 2005, p. 441).

\subsection{Bounded Territories}

The idea of community may foster insular thinking that regards a community as a closed, bounded space. At best this leads to a neglect of places outside the 
territory of a community. This is most clearly envisaged when one village adopts a territorial crime-prevention scheme and crime is displaced to others that have not (Johnstone, 2011). At its worst, territorial policing can be used to exclude some groups of people from particular spaces. In urban areas there are many examples of community and territory being used to cleanse space, often to support neo-liberal programmes of investment (Herbert, 2005; Mitchell, 1998; Paasche et al., 2013; Samara, 2010).

As noted in section 2.1, there are dangers that partnerships in rural areas might empower rural elites to exclude people on the grounds of cultural rather than criminal threat (Yarwood, 2010a). These have been viewed as a way of enforcing a particular moral order (Coleman, 2004) that shows little evidence of respect or tolerance towards others (Fyfe et al., 2006). One example of a community-based crime and safety partnership scheme in rural England centred on 'designing crime out' of its village and was directly largely at young people who were deemed to be out of place by 'hanging around' certain locations (Yarwood, 2010a).

Similarly, Neighbourhood Watch, one of the most ubiquitous forms of community policing, relies on the use of territory for its power (Yarwood and Edwards 1995) and is widely found in wealthier rural places (Fyfe 1995a). Although most schemes are innoxious enough, largely because they are dormant, NW represents an attempt to treat public space as private, to be used as a preserve for those who are known to and accepted in a neighbourhood (Yarwood 2012).

\subsection{Relational Policing Networks}


The idea of community can, therefore, problematic and there is a need to reconsider how place-based forms of policing operate. It is important that both the practice and research of rural policing considers a community as something more than a bounded space. Although some local crime and safety partnerships rely on local goodwill, resources and social capital, these are linked to much wider networks of national and international policing. Communities are connected to social, economic and political networks that stretch beyond the immediate locality (Massey, 1991, 2005).

Relational approaches have been used effectively to progress understanding of farming practices, development and human-nature relations (Murdoch, 2006) but they have yet to be applied to policing practices. They are helpful because policing covers an extraordinary range of activities, from riot control to community liaison. Depending on what is being policed, different technologies, people, institutions, animals, knowledge, performances and practices will be enrolled into certain spaces in different ways to create assemblages of 'policing' to produce moments of stability in an otherwise fluid society (Murdoch, 2006; Whatmore, 2002). As no two situations are the same, policing is a heterogeneous activity that involves different combinations of actors, equipment and skills operating in very particular environmental circumstances (Yarwood, 2010b). Thus, network approaches can be used to consider how different assemblages of policing crystallise in rural places in particular situations. The following section applies these ideas to police searches for missing people

\section{Policing Missing People}


Research has tended to focus on the ways in crime and the fear of crime are policed in rural areas (Mawby and Yarwood, 2011), yet the police also have a remit to provide public safety. A particularly important aspect of this is searching for people who are lost or missing. Parr and Fyfe (2013) have examined the ways in which the police develop an 'investigative methodology', based on experience and previous cases, to speculate on the events leading up to a person's disappearance. In light of this knowledge searches are planned that enrol a wide range of agencies, practices and technologies (Yarwood, 2010b, 2012). Searches in rural areas are particularly challenging as they require policing networks to stretch across a range of challenging and sometimes hostile terrains and weather conditions. Amongst other things searches in rural environments draw upon specialist technologies (for example helicopters equipped with surveillance equipment), knowledge (gained by experience, training and data from previous searches (Koester, 2008) and, significantly, agencies other than the police.

Over time, the composition of these networks and the ways that they perform policing has changed. Fifty years ago, searches for missing people were ad-hoc, community based affairs. For example, in New Zealand and the United Kingdom, local walking and sports clubs were called upon to join informal search parties when someone went missing in rural places (Yarwood, 2010b; Yarwood, 2011a). Tourists, perhaps staying in local hostels or hostelries, might also get called to help with these searches but, in the main, responses came from within local communities. Over time, some walking clubs started to form themselves into search teams. What they lacked in formal training or sophisticated equipment, they made up with excellent knowledge of local landscapes as well as the fitness and skill to traverse them in all weathers. The emphasis was on drawing upon resources from within a community. 
The search for missing people has become more formalised, largely in response to legislation and policy that has placed a responsibility on the police to locate and care for them. Article 2 of the European Convention on Human Rights (ECHR), for example, specifies a 'positive duty to protect life in certain circumstances'. All European police forces therefore are obliged to take seriously and response fully to a report of a missing person for 'failure to properly investigate a report of a missing person may leave an individual at risk and the Police Service vulnerable to a legal challenge under either the Human Rights Act or the law relating to negligence' (Association of Chief Police Officers, 2010, p. 15). Given these legal obligations to search effectively for missing people police forces have developed procedures that are required to be followed when someone goes missing.

In the UK, the Association of Chief Police Officers (ACOP) defines a missing person as 'anyone whose whereabouts cannot be established and where the circumstances are out of character or the context suggests the person may be subject of crime or at risk of harm to themselves or another'1 (Association of Chief Police Officers, 2013, p. 5). When someone is reported missing, the police undertake a risk assessment ${ }^{2}$ that, in turn, triggers the 'speed and scale of the initial police response' (Association of Chief Police Officers, 2010, p.15)

\footnotetext{
${ }^{1}$ A second definition of an 'absent' person applies to "A person not at a place where they are expected or required to be." In practice this refers to a secondary, less urgent category of missing person where immediate harm to him/herself or others is less likely and, in part, responses to a person's right to go missing if they desire to. Cases are monitored and upgraded to 'missing' if necessary.

${ }^{2}$ Definitions of missing can include people abducted by force or subjected to trafficking or forced labour. This infringes on other rights defined by ECHR, viz: 'the right not to be subjected to torture or to inhuman or degrading treatment (Article $3 \mathrm{ECHR}$ ); the right to prohibition of slavery and forced labour (Article $4 \mathrm{ECHR}$ ); the right to respect for private and family life (Article $8 \mathrm{ECHR}$ ); the right to freedom of expression, including freedom to receive information (Article $10 \mathrm{ECHR}$ )' (Association of Chief Police Officers 2010: 15). ACPO guidance issued in 2010 (15) states emphatically 'if in doubt treat as murder'. See Parr and Fyfe (2013) for more on police procedures for missing people.
} 
The search for missing people is a multi-agency affair that draws upon various other public, private and voluntary organisations as appropriate. In rural areas, the police make use of specialist agencies to help them with searches in mountainous, coastal or fluvial areas that may be dangerous to non-specialist police units. Yet the responsibility for locating missing or lost people remains with the police: they must be confident that other agencies can work effectively in partnership with them to search for missing people and can do so and effectively and, importantly, safely. The Royal Canadian Mounted Police (RCMP) acknowledge that 'properly trained civilian volunteers can be equally as effective as highly trained paid professionals' with the proviso that they should be trained to 'recognize clues and will not destroy evidence, injure the lost person or become lost or injured themselves.' (http://www.rcmpgrc.gc.ca/ccaps-spcca/rs-eng.htm). Consequently they are able to draw a wide range of professionals and volunteers resources in a Search and Rescue (SAR) operation, which include:

- police service dog teams;

- trained volunteer SAR civilian dog teams;

- trained volunteer or RCMP Hasty Teams;

- RCMP helicopter equipped with Forward Looking Infrared (FLIR);

- trained volunteer "specialist" teams (avalanche, white water, ice rescue, etc.);

- trained volunteer SAR divers and RCMP Dive Teams;

- trained human trackers and other SAR trained persons (http://www.rcmpgrc.gc.ca/ccaps-spcca/rs-eng.htm). 
To ensure safe and competent working, police forces in many countries have entered into formal agreements with volunteer teams to provide search and rescue in rural places. In New Zealand, for example, a formal compact has been signed between rescue teams and the police to provide a search and rescue service. This has led to centralised funding but also a required for volunteers to undergo formal training and to standardise search procedures across the country (Yarwood, 2011a)..

The consequence of this 'professionalization' is that voluntary teams can be deployed with the police in a wide range of environments. Their deployments are not confined to a particular community but can range across wide regions. Thus, the search skills developed by rescue teams in mountainous areas are increasingly being deployed in urban situations (Yarwood, 2010b). These geographies emphasise that the deployment of voluntary search teams is no longer 'community based' but, instead, is driven by a whole series of relational networks that link localities to wider national and international legislation and policing practices. This is a far cry from the ad-hoc, 'community based' searches of the past, which rarely followed established search procedures and could place their participants, as well as the missing, in considerable danger.

There are, of course, times when lay people will seek to help in searches that are close, geographically and emotionally, to their community. In 2012 a young girl went missing from her home in Machynlleth, West Wales, which prompted an impassioned response from many local people who turned out to look for her. The police had to manage these volunteers in a way that utilised their goodwill whilst, at the same time, ensured that evidence was not destroyed and that they were not put in danger themselves. Trained volunteers, including Mountain Rescue Teams and 
voluntary search-dog teams from across and beyond Wales, were used to search more hazardous locations such as rivers ${ }^{3}$.

Search and Rescue operations therefore reflect a networked approach to understanding policing. Although volunteers may be familiar with a particular locality, they are not 'community based' as their actions are determined by policing networks that manifest themselves in particular sites at particular times of emergency. How the police and their partners respond and act varies with circumstance but is determined by national procedures. Particular localities provide important contexts for rescue teams that are understood as 'taskscapes' (Ingold 1993) that bind a landscape's histories, features and landscapes together with the working lives and practices of a rescue team. The practices of a search engage teams bodily and emotively with rural landscapes through the mediation of specialist technologies and knowledge (Yarwood, 2012). In doing so, different embodied practices, human and non-human actors, knowledges, technologies and agencies are all enrolled into hybrid networks in order to execute different searches in different places (Parr and Fyfe, 2013; Yarwood, 2010b). Search dogs provide an example of this.

\subsection{An Introduction Search Dogs}

Dogs are an important, but to date neglected, part of searches for missing people. Whereas humans rely largely on sight to search for missing people and move relatively slowly over broken ground, especially when encumbered with equipment and rescue gear, dogs use scent to locate casualties and can move far more nimbly than human teams across rural terrain (Figure 1). Both of these

\footnotetext{
${ }^{3}$ Her body was never found but Mark Bridger has been convicted of her murder.
} 
characteristics greatly increase the probability of detecting a missing person, especially in remote places where conditions and terrain challenge people's ability to spot casualties.

\begin{tabular}{|c|c|c|c|}
\hline Year & Callouts & People & Finds \\
\hline 2013 & 92 & 125 & $5(5 \%)$ \\
\hline 2012 & 118 & 140 & $14(12 \%)$ \\
\hline 2011 & 135 & 153 & $23(17 \%)$ \\
\hline 2010 & 134 & 134 & $16(12 \%)$ \\
\hline 2009 & 168 & 168 & $18(10 \%)$ \\
\hline 2008 & 169 & 169 & $38(22 \%)$ \\
\hline 2007 & 109 & 109 & $11(10 \%)$ \\
\hline
\end{tabular}

Table 1: Call-outs involving search dogs in England 2007-2013 (Source: SADRA, England)

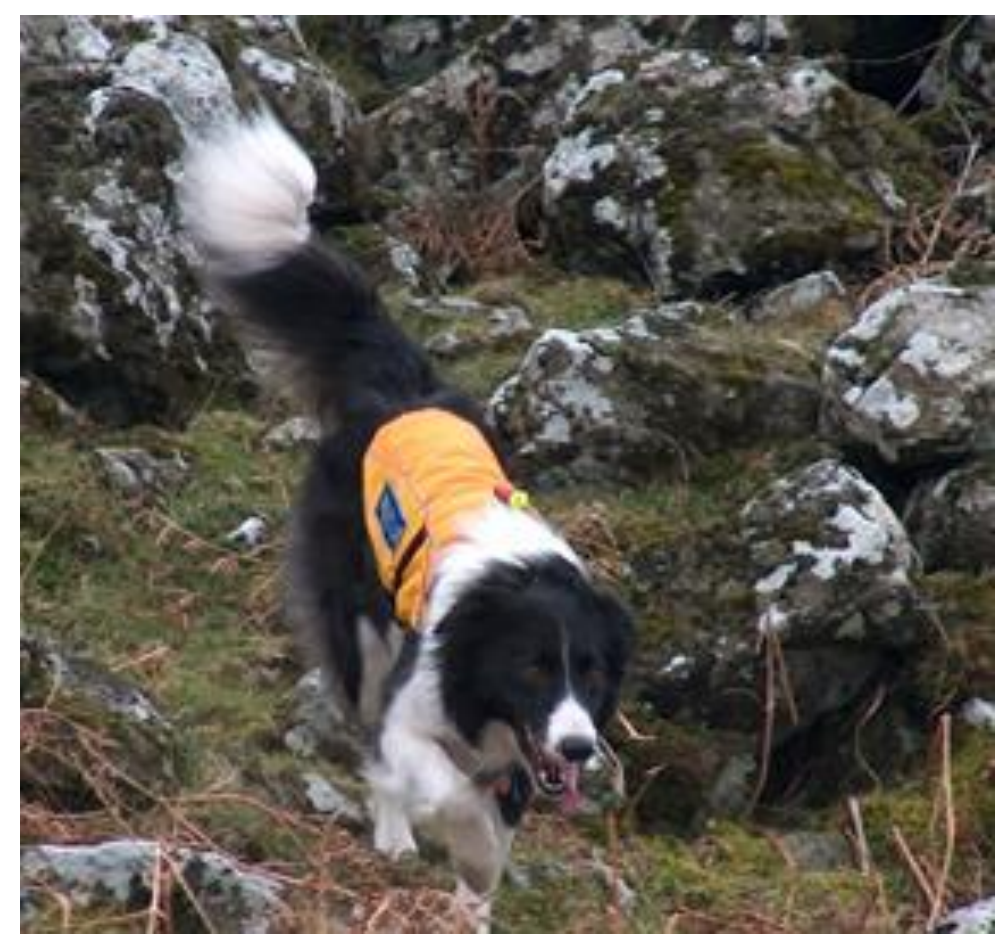

Figure 1: A search dog ranging over clitter. The luminous bid with strobe ensures the dog can be seen by people but also acts as a trigger to encourage the dog to work 
Although the police train animals as 'general purpose dogs' to undertake a range of tasks, specially trained dogs and handlers are needed for searches in rural, wild or mountainous terrain. In the UK, this mantle falls on dogs that are trained and handled by civilian volunteers who are existing members of mountain or lowland rescue teams. These dogs are deployed by civilian or police search managers in response to emergency calls to locate missing people (Table 1). Between 2010-2013, $70 \%$ of call-outs recorded by SARDA England and over half dog 'finds' were for 'vulnerable people' (including people who were despondent, had Alzheimer's disease or dementia, had absconded from care homes, were ill or may have misused substances ${ }^{4}$ ), reflecting a general increase in these categories of call-outs made to MRTS (Yarwood, 2010b).

To date, little attention has been given to the role of animals in policing work, despite a burgeoning literature on both policing and animal geographies. Likewise, although a significant literature has explored explore human-animal relations in rural spaces (Jones, 2003), curiously little has been written about the place and role of dogs in the countryside (Brown and Dilley, 2012). This is despite a growing literature on the ways that the human-dog relations shape, and are shaped by, urban environments (Laurier et al., 2006; Power, 2008; Power, 2012; Urbanik and Morgan, 2013). In a rural context, Brown (2014) has examined how legal and moral norms are mobilised to regulate the behaviour of pet dogs in the countryside. Little consideration, though, has been given to role of 'working dogs' despite their significance in rural places. Sheep dogs, for example are essential to the practices of upland farming and hounds are essential to country pursuits such as hunting or shooting (Woods, 1998).

\footnotetext{
${ }^{4}$ See Parr and Fyfe (2013) for a more nuanced approach to understanding missing people.
} 
Consequently, this paper continues by examining the role and contribution of $\operatorname{dogs}^{5}$ to police-led searches in rural places. This not only allows greater insights into rural policing networks but the role of non-humans agencies in these networks and, more broadly, rural space itself. It responses to Powers' $(2008$, p. 537) call to examine how 'dogs are entwined in unique, open-ended encounters' with people and places. The next section examines how search dogs are regulated and used in networks of police searches. The next section draws on interviews with the handlers of search dogs that are members of a Mountain Rescue Team in the South West of England to the examine the hybrid nature of human-dog relationships and their significance to rural policing and the search for missing people.

\section{Pets that Work: Enrolling Dogs into Police Networks}

Dogs are enrolled into searches as they possess bestial attributes that make them useful to human actors, yet this animality must be coerced and controlled (Tuan, 1984) to be of value in human-centric search networks. This is achieved through an intensive training process that is regulated by the National Search and Rescue Dog Association (NSARDA) in the UK, together with its associated national and regional branches. A dog is trained with a specific handler who owns the animal and is already a member of a Mountain or Lowland Rescue Team (and so has already been enrolled into the networks of the emergency services).

Although any breed of dog may be trained as a search dog, 'working dogs' such as Collies (which make up approximately half of NSARDA's search dogs in Engand), Labradors, Alsatians and Spaniels are viewed more favourably as they are

\footnotetext{
${ }^{5}$ The paper focuses on civilian search dogs trained by volunteers to work in rural and mountainous environments rather than professionally trained 'general purpose' police dogs.
} 
deemed to have the characteristics and temperament, themselves products of centuries of selective breeding (Clutton-Brock, 1999), that allow them to be trained to behave particular ways. Sometimes, therefore, a member of a MRT will acquire a specific breed with the intention of training it as a search dog. On handler commented of his dog

"She is a four-year- old Australian kelpie, which is like a super collie, all the traits of a collie that you'd expect, and it really wants to work"

It is pertinent here to note that all search dogs are kept, fed and maintained by their owners. They are regarded as "a pet first, really. Yes, definitely. You know, he sleeps under the bed or in the bed." They live in their homes and take part in walks, play and other activities associated with domestic dogs (Power, 2008; Power, 2012). Indeed, it is sometimes during these playful activities in which a dog's potential is spotted:

"he was good at finding, every time I went out for a walk he'd find a ball ... And he'd be digging under hedge and everything, you know, so he had a good nose. And even when I used to throw a ball for him in long grass, I'd pretend to throw it one way, he'd run off and l'd throw it behind me so he'd have to smell the ball out, you know, he wouldn't be able to find. But he enjoyed doing that"

To qualify, potential search dogs are required to undertake a four stage training programme. The 'puppy' stage concerns basic obedience training that first 
centres on a dog learning its name. This also serves as a command to get the dog's attention and warn it to anticipate a command. It is also crucial that dogs are 'stock' compliant. Although the 'Countryside Code' (Brown and Dilley, 2012) recommends that dogs are kept on a lead in areas where animals graze, search dogs are required to work off a leash. Handlers must ensure that when doing so their dogs will not worry livestock or be distracted by them when searching. It also illustrates that dog teams are required to work in relation to other rural practices and agencies, in this case those in farming, and must fit into the moral landscapes of the countryside. Brown (2014, p.5) argues that human-animal relationships are 'infused with moralities' that are dependent on how animals ought to be as they 'become-with' humans in particular places and landscapes. This is re-enforced through various stages of obedience training that involves:

"getting the dog to walk to heel, getting him to lie down and lie down on a recall: so they're coming back to you at speed and then they have to lie down. They have to do a 'down', stay for ten minutes, which involves you're going out of sight for two or three minutes as well. So it's a lot of training and that can take anything up to a year, between sort of eight months and a year"

Although some of these are common to the training of any dog, potential search dogs are also taught to bark or 'speak' on command. This is to prepare a dog for indicating when it has found a casualty and helps establish ways of communicating between handler and animal. 
Teams passing the Puppy Stage move onto Stage One in which dogs are taught the 'find sequence.' This involves working with simulated casualties, known humorously as 'Dogsbodies', who will:

"start running off to a bush or a rock, carrying the dog's favourite toy, a tennis ball or whatever it is, but that dog will then see somebody else, other than the handler, running off and carrying the ball. You then release the dog; the dog loves the toy, wants its toy, so it runs after the casualty. When the casualty is with the dog, the dog then gets the toy. We then build that up, build it up to where the casualty does not release the ball or the toy until the handler is with the casualty"

As this stage develops, the dog is taught to indicate (bark) that is has found a casualty and to guide the handler towards it. Stage 2 involves the dog teams searching for 'Dogsbodies' whose locations are known to the handler but not the dog. Here the dog is taught to 'range', that is run ahead of the handler in order to locate and follow an air scent to a casualty.

Again, the dog must indicate and lead its handler to the 'Dogsbody'. The final stage of training repeats this process but without the handler knowing where the bodies are located. The final assessment requires dog teams to find casualties hidden to both dog and handler on mountainous terrain. If this is passed, the dog is 'graded' and can be called upon to take part in real searches.

Training continues after badging with other dogs, handlers and their MRTs. Indeed, repetitive performances are essential to creating the identity of a search dog: 
"They used to give us something to do and I just keep working on that, working on that till we got it to perfection, and then go with that and say I'll do this now. This is repetitive really, it just becomes a habit for them basically, you know, like any command"

Play and rewards are an important part of this process:

"The dog is rewarded all the time with their favourite toy, it could be a tennis ball, squeaky hammer, whatever you can get from a pet shop, but whatever makes the dog tick, really ... it is the desire for the toy ... she's associating human scent with the toy"

As this quote suggests, there is a fine line, or perhaps none at all, between work and play in a dog's mind. For people, a dog's identity is relational to the people around it, the task it is required to perform and, significantly, what space it occupies. In the home, the vast majority of search dogs are viewed as pets that are part of the handler's family (Power, 2008). Yet, on a call-out, the handler requires the dog to perform in certain ways that are equated with the work of a search. Certain technologies are used to encourage the dog to 'work', including a bib that is only worn by dogs when working (Figure 1) and serves as a trigger:

"It's the working jacket. The working jacket with bells and lights on it. So she can see and we can see her... she also knows when I get all my rescue kit ready, putting in the car, she knows that we're going out to work. And she absolutely loves it" 
As this quote suggests, taking a dog outside its home territory also acts as a trigger, which might be problematic if a search is called in an area well-known to a dog:

"The one we did in [name of place] the other week, at [name of farm]. And we went on that and I said, 'Look, I don't know if he's going to work or not here because we walk on here every day" (Laughs)"

This comment reflects that knowledge of a dog's territory and also ability to range outside it with a human companion is essential in their deployment on a search. The following section explores this in more detail.

\section{Searching Nature: The Nature of Searching with Dogs.}

Search-dog teams illustrate the need to pay attention to the "livingness" of the dog and the "intimate fabric of corporeality" of the human-dog relationship' (Urbinak and Morgan $(2013,293)$. Thus one dog handler argued that the key to an effective partnership was being able to sense the landscape in the same way as a dog:

"Just remember, you're not searching the ground, you're searching the wind that blows over the ground. So wind direction is absolutely key to us when you are searching" 
Search dogs are trained to locate non-moving casualties primarily by attempting to locate and follow the air-scent that is emitted by a person. As Figure 2 demonstrates in a simplified way, scent carried down-wind and diffuses as a cone. As one handler said:

"The dog does all the work, but the handler has to put the dog in the right position to do the work. That's another key thing. You have to make sure you're covering the ground in the right way"

A handler will therefore attempt to make his or her dog 'range' across terrain to detect this scent (Figures 1 and 2). Two handlers discussed how they walk in certain ways to encourage this behaviour:

"the handler is doing a zigzag pattern ... so the dog's responsive to the handler and she will go off in a direction that she sees me walking in. So she's always fifty to a hundred metres ahead of me. If I encourage her to walk off into one direction in a zigzag, she'll go off in that direction for another sixty, seventy metres. Once I see her moving on that bearing, I may turn round and zigzag the other way while she's still going that way"

"I really try to search a swathe, so he searches to the left of me and to the right of me. But if I want him to search more to the right, or if he's doing more to the left than I think he should, I will then walk off in the direction towards the right. He will see that l've changed direction and he will then come across me, 
straight across me and then carry on to search to my right until I think he's gone far enough, then I will go straight again"

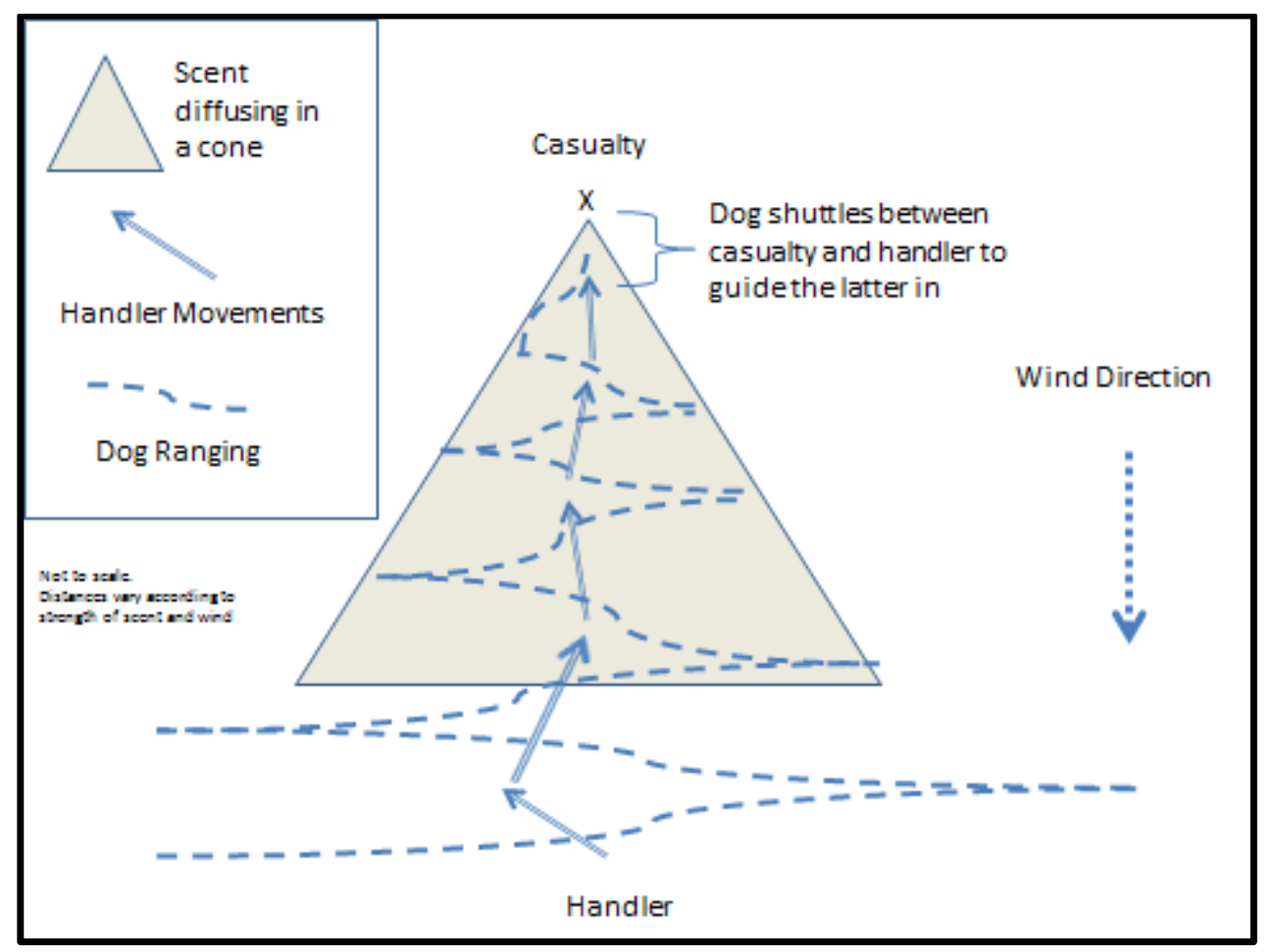

Figure 2: A simplified diagram of how a search dog locates a casualty.

Ideally, the dog will detect a scent and then follow to its apex and therefore the casualty. The dog will then bark to indicate 'a find' (Figure 3 ) before returning to the handler (figure 4). The dog will then guiding him or her to the casualty by running backward and forwards between the two (5) in ever short shuttles until the handler arrives at the casualty site (Figure 6). Figures 3, 4 and 6 demonstrate how hard it is for a person to see a prone casualty. In this case it is a training exercise with a 'Dogsbody' who has dressed in dark clothing and camouflage to make it harder to be seen by the human handler, who must rely on his dog's ability to detect and follow 
scents. Dogs clearly have an advantage over humans in conditions of poor visibility, although the ability to follow air scents is reduced if the wind is still or very strong.

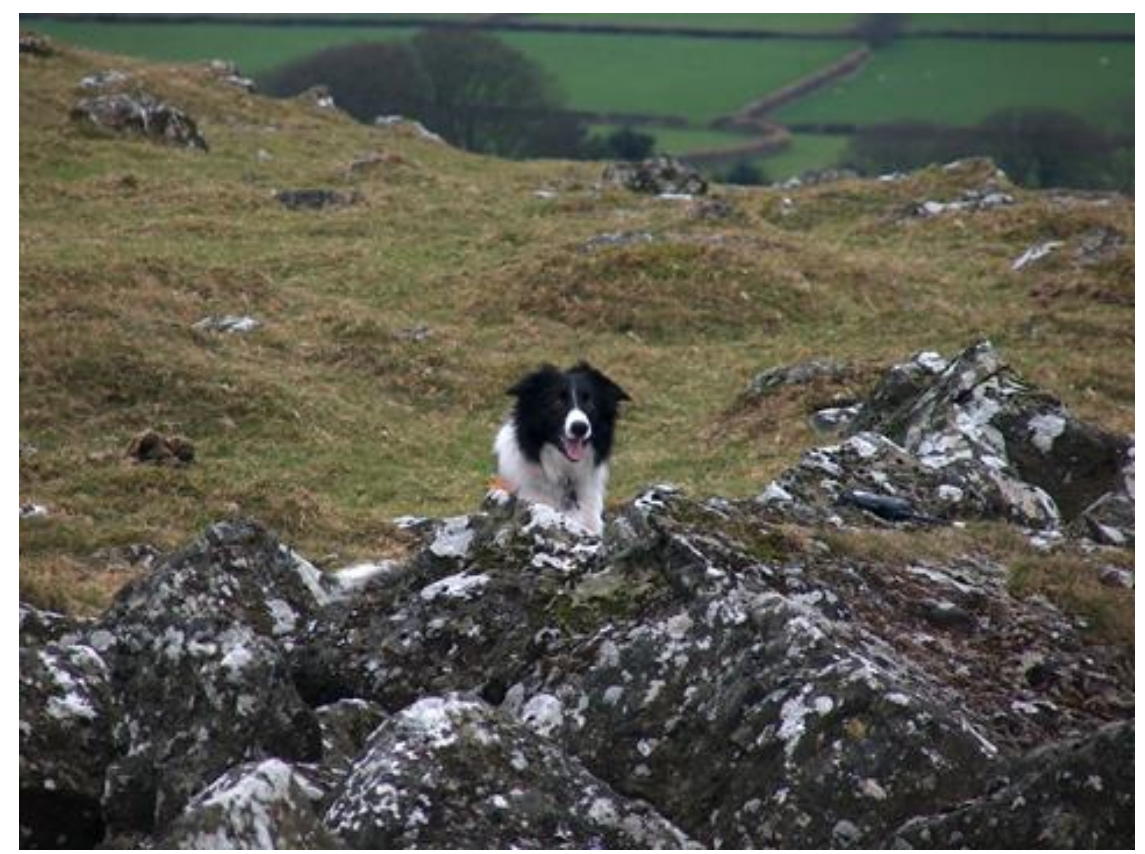

Figure 3: Indicating a find behind a rock. The casualty is invisible to a person who searches by sight but is clearly present to a dog using air scents. 


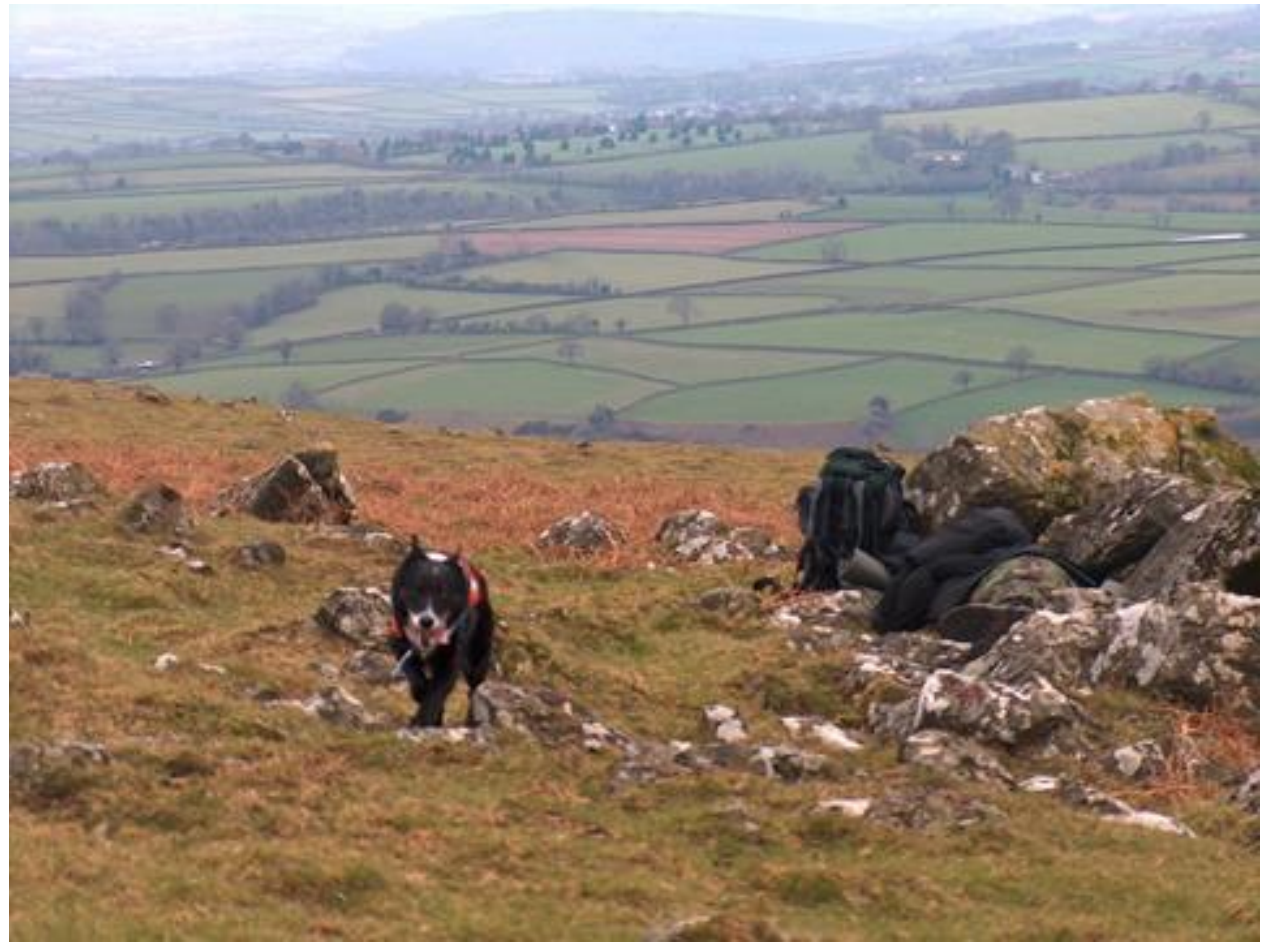

Figure 4: Returning to the handler

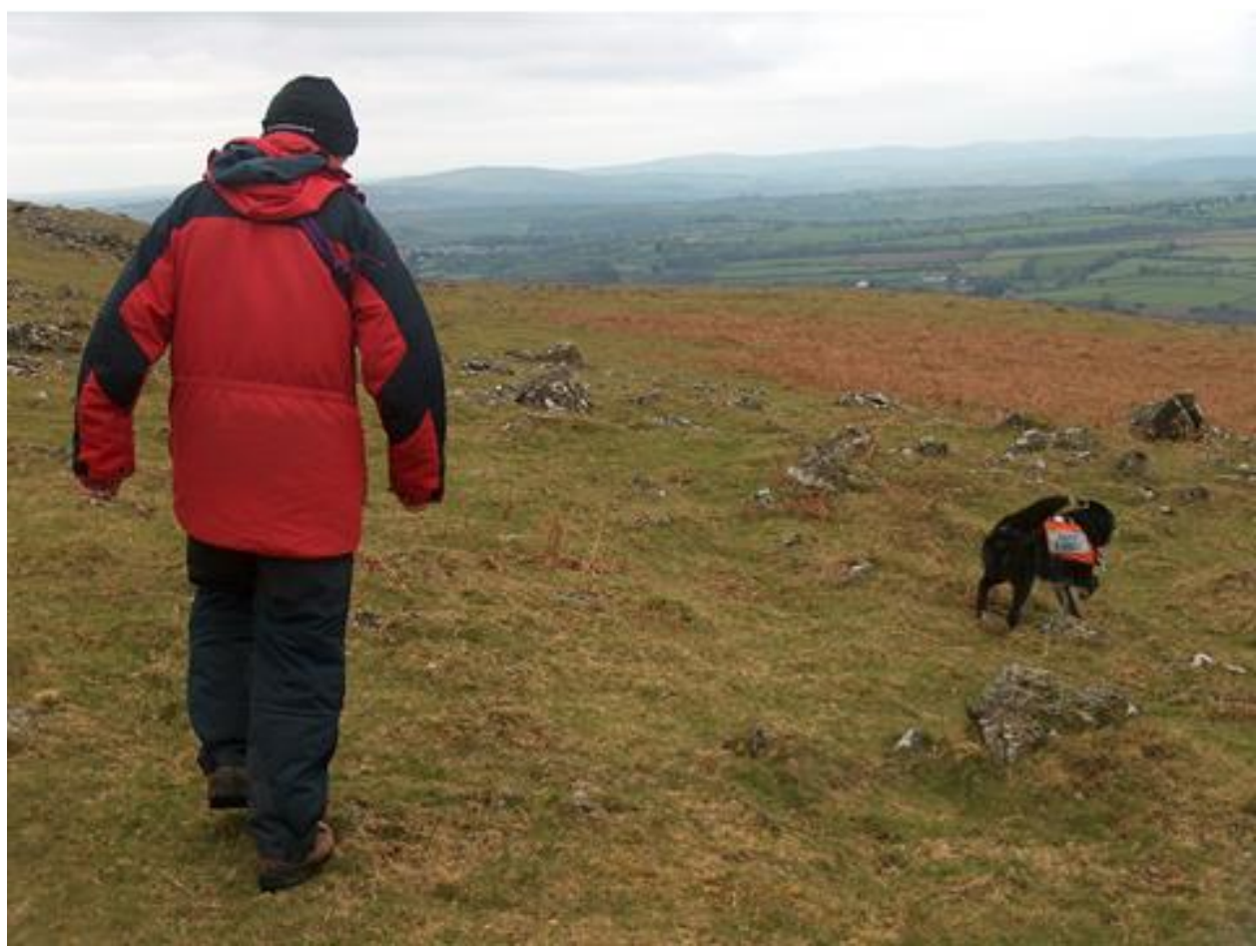

Figure 5: Guiding the handler towards the casualty by shuttling between the two 


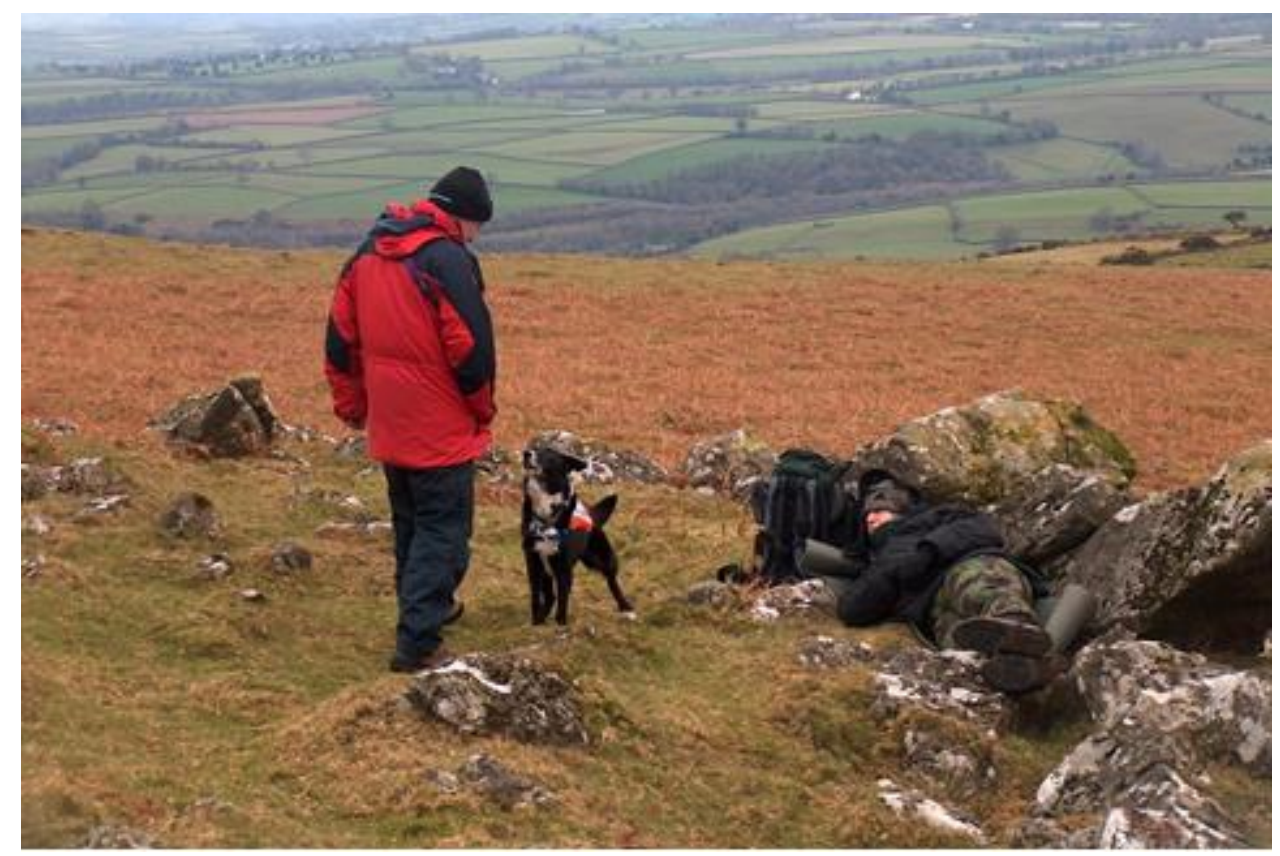

Figure 6: A successful find. The casualty can just be seen lying by the rocks to the right of the dog.

To increase the chances of a find, handlers need to work in relation to the wind, the terrain and, most significantly, the way these effect their dog. Efforts to sense the landscape in the same way as their dog, may influence how a search is conducted. This, searches may start in 'collecting areas' such as walls or hedges that are downwind and may trap scents. A dog will, "go along walls, wall ledges and sort of thing, where the scent can turn, and pull around and go in a different direction". With experience, handlers and their dogs can use very subtle variations in micro-climatics:

"we had incredible find when the first aid casualty was right at the top of the bank, wasn't he, he must have been a hundred, two hundred yards away, right at the very top by the fence, and he'd picked up the scent from by the 
river. But that's because as it cools down the air temperature then goes down to the river, it's dragged down to the river level rather than in the summer with the heat in the day, the heat is rising from the river up to the top of the hill"

Often handlers must rely on the dog's ability to scent rather than their own ability to see casualties. This is something that is learnt by experience and continual repetitive training:

"you have to trust the dog is doing the right thing. So many times l've thought that no, they're not down there, they can't possibly be down there, I'm going to call the dog off, there's no way ... but you should generally trust the dog, follow it up"

The ability to notice and understand when and how a dog is indicating is built up over time. Handlers only work with their dog for:

"every dog has a slightly different characteristic. That's why it takes so long until you know your dog inside out. My dog, her ears go back when she's found, head's lifted in the air, starts sniffing and then her ears go right back and she tilts towards the casualty, or the stronger scent"

One handler reported of a training exercise: 
"I could tell as we got along he was getting more and more interested ... he's running with a little bit more enthusiasm, his eyes are brighter (laughs) ... it's usually in his face as well, usually the way he looks at me as well, you know, his reaction"

The way that dogs 'range' (run ahead of their handler) can also offer clues. One dog will stay relatively close to her handler unless:

"she's on a strike ... the mere fact that she's going more than fifty metres away from me makes me instantly realise that there's human scent on the end of it ... and so she's a good tool in the fact that I know that if she breaks that fifty-metre boundary she's on to something."

The comment reflects that the dog has an identity as both an animal and an asset or 'tool' that is useful in police searches. Equally, one handler thought that dogs learnt about human behaviour and modified their own accordingly:

"they memorise where they're found. You know, I mean a lot of people hide at the top of tors and things like that. So if there's a tor or a lump of rocks or a big lump of grass or something, or anything obvious, he will go and investigate that even though there's no scent"

Indeed, the same person suggested that communication can be quite complex between the pair: 
"I think what he has started doing is that if he picks up a scent and he thinks I'm going off in the wrong direction, he'll come back and indicate, and then he'll go back to where he picked the scent up and carry on searching. I've noticed that. So rather than going all the way into the body and me being further away, he's got clever and he'll stop me from going too far" As this final example shows, this is hybrid ...

"sometimes he will come back and I'll hang back a bit and I'm looking at him, waiting for some response from him and I think I'm probably inducing an indication, which is inducing a bark. But once he barks, l'll say, "Show me," but he will not go back to where he came from, he will then carry on in a search pattern"

As these example suggest, interactions between handler and dog are complex and subtle. It also requires complete sensory immersion between the pair 'because if you look down at a map ${ }^{6}$ to check where you are for a few seconds, you could miss a head lift or a nose on the ground'. Not only does the handler need to read how his or her dog responses to landscape and the wind blowing over it, but the dog must also learn to respond to and react to how his or her handler behaves. A successful search team is, therefore, a genuinely hybrid infusion of person and dog.

\footnotetext{
${ }^{6}$ For this reason a navigator is often deployed with a dog-team who is a member of an MRT. When undertaking this role it is imperative that they do not come between the dog and its handler so as not to interrupt communication between the two.
} 


\section{Conclusions}

This paper has attempted to use the example of civilian search dogs to draw together two areas of rural studies: how the countryside is policed and the place of animals in rural places. The empirical section necessarily focused on the relationship between the dog and its handler. If at times this detail seems removed from the work of policing, it contributes to Parr and Fyfe's (2013, p. 4) call more for 'nuanced understanding of the spatiality of police work.' In this case, the empirical material shows how a dog-team is a hybrid entity in that it enrols a person and a dog; sight and sound; dominance and affection (Tuan 1986) as well 'nature' (in the form of the wind) into searches for missing people.

The abilities of search dogs also contribute to hybrid understandings of absence. Parr and Fyfe (2013) have challenged the binary of absence/presence in landscapes, supporting work that seeks to address the complex and emotive aspects of 'absent geographies.' Whilst a missing person might be out of sight, and hence missing, to people, their lingering scents mean that they continue to have a presence to animals and, in this case, search dogs. The example reminds us that what might be an empty landscape to a person, may be one that is brimming with activity and bodies to dogs (As Figure 3 illustrates or rather it doesn't to the human observer!).

Viewed anthropocentrically dogs have an ability to use clues that, to a person, are simply not there. One experienced handler noted:

"They appear to have a sixth sense when there is nobody in the area and they know if you have strayed back into an area where you have previously searched. This can happen in inclement misty weather especially in the dark" http://www.dartmoorsartplymouth.org.uk/how-we-help-you/search-dog-team/ 
This reference to a 'sixth sense' hints at 'an approach which focuses on being-in-the-world can draw attention to the mystery, spirituality and ghostliness of rural places' (Cloke, 2003, p.6). Although a dog should not been confused with the reversal of its spelling, its sensory abilities seem almost supernatural and can provoke re-engagement and 're-enchantment' with animality, rurality and nature. Although animal geographers encourage us to see the world in less anthropocentric terms, animals may nevertheless continue to astound and confound people with their abilities and senses.

Even though a handler has learnt how to work his or her dog according a knowledge of scent and the wind, it is important not to underestimate the affective bond between person and animal. This is frequently expressed through astonishment at a dog's ability and play as a reward for finding a casualty. To the dog play is also important as a successful find, be it in training or for real, "equals a fun, happy time and I'm going to get a game with my favourite toy". Affect and emotion are glues that help bond person and dog into the networks of a police search.

Networked approaches help to understand how different elements of policing are pieced together in a locality and work in relation to each other. Thus, dogs play an important part in the 'architecture' of a wider search (Parr and Fyfe 2013) by scouring rural terrain, a task that usually involves other agencies including Mountain or Lowland Rescue Teams and the police. At the same time, the police and other teams may be searching urban places or private residents. Although dogs have a high probability of detecting someone in their area, the apparent ratio of calls-outs to finds is relatively low (Table 1) because people are frequently found outside the 
dog's search area by the police. This emphasises that search-dogs are but one element part of a search for a missing person. They are unable to work alone but rely on handler and the wider search to be deployed.

This paper has consider one aspect of rural policing (searches for missing people) but the principle of understanding how a search relies on a relational network is of wider significance. Returning to the assertions made at the start of this paper, community-based policing in rural places must similarly recognise how it is linked to wider networks and work in relation to them. This should not preclude community-centred approaches but, rather, should recognise that community in itself should not be a way of recognising or indeed organising rural policing.

\section{Bibliography}

Anderson, J., Tressider, J., 2008. A Review of the Western Australian Community Safety and Crime Prevention Partnership Planning Process. Australian Institue of Technology, Perth.

Association of Chief Police Officers, 2010. Guidance on the Management, Recording and Investigation of Missing Persons, 2nd Edition, London.

Association of Chief Police Officers, 2013. Interim Guidance on the Management, Recording and Investigation of Missing Persons 2013. Association of Chief Police Officers, London.

Brown, K., Dilley, R., 2012. Ways of knowing for 'response-ability' in more-thanhuman encounters: the role of anticipatory knowledges in outdoor access with dogs. Area (44), 37-45. 
Brown, K.M., 2014. The Role of Landscape in Regulating (Ir)responsible Conduct: Moral Geographies of the 'Proper Control' of Dogs. Landscape Research1-18.

Buller, H., 2014. Animal geographies I. Progress in Human Geography (38), 308-318.

Cloke, P., 2003. Knowing ruralities?, in: Cloke, P. (Ed.), Country Visions. Routledge, London, pp. $1-13$.

Closs Stephens, A., Squire, V., 2012. Politics through a web: citizenship and community unbound. Environment and Planning D: Society and Space (30), $551-567$.

Coleman, R., 2004. Reclaiming the Streets. Willan Publishing, Cullumpton.

Clutton-Brock, J., 1999. A Natural History of Domesticated Mammals. Cambridge University Press, Cambridge.

Cunneen, C., 2001. Conflict, politics and crime: Aboriginal communities and the police. Allen and Unwin, New South Wales.

Desforges, L., Jones, R., Woods, M., 2005. New Geographies of Citizenship. Citizenship Studies (9), 439 - 451.

Fyfe, N., Bannister, J., Kearns, A., 2006. (In)civility and the city. Urban Studies (43), 853-861.

Fyfe, N.R., 1995. Law-and-order policy and the spaces of citizenship in contemporary Britain. Political Geography (14), 177-189.

Gilling, D., 2011. Governing crime in Rural UK: risk and representation, in: Mawby, R., Yarwood, R. (Eds.), Rural Policing and Policing the Rural: A Constable Countryside? Ashgate, Farnham, pp. 69-80. 
Herbert-Cheshire, L., 2000. Contemporary strategies for rural community development in Australia: a governmentality perspective. Journal of Rural Studies (16), 203-215.

Herbert, S., 2005. The trapdoor of community. Annals of the Association of American Geographers (95), 850-865.

Herbert, S., 2006. Citizens, Cops and Power: Recognizing the Limits of Community. University of Chicago Press, Chicago.

Higgins, V., Lockie, S., 2002. Re-discovering the social: neo-liberalism and hybrid practices of governing in rural natural resource management. Journal of Rural Studies (18), 419-428.

Johnstone, C., 2011. Big brother goes to the countryside: CCTV surveillance in rural towns, in: Mawby, R., Yarwood, R. (Eds.), Rural Policing and Policing the Rural: a constable countryside? Ashgate, Farnham, pp. 81-92.

Jones, O., 2003. 'The restriant of beasts': rurality, animality, Actor Network Theory and dwelling, in: Cloke, P. (Ed.), Country Visions. Pearson, Harlow, pp. 283307.

Koester, B., 2008. Lost Person Behaviour. dbS Productions Ltd, Virginia.

Laurier, E., Maze, R., Lundin, J., 2006. Putting the dog back in the park: animal and human mind-in-action Mind, Culture \& Activity (13), 2-24.

Liepins, R., 2000. New energies for an old idea: reworking approaches to 'community' in contemporary rural studies. Journal of Rural Studies (16), 23-35.

Lockie, L., Lawrence, G., Cheshire, L., 2006. Reconfiguring rural resource governance: the legacy of neo-liberalism in Australia, in: Cloke, P., Mardsen, T., Mooney, P. (Eds.), The Handbook of Rural Studies. Sage, London, pp. 29-43. 
Massey, D., 1991. A global sense of place. Marxism Today (June).

Massey, D.B., 2005. For space. SAGE, London ; Thousand Oaks, Calif.

Mawby, R.I., Yarwood, R., 2011. Rural Policing and Policing the Rural: A Constable Countryside? Ashgate, Farnham.

Middleton, J., Yarwood, R., 2013. 'Christians, out here?' Encountering Street-Pastors in the post-secular spaces of the UK's night-time economy. Urban Studies.

Mitchell, D., 1998. Anti-homeless laws and public space: I. Begging and the first amendment. Urban Geography (19), 6-11.

Mouhanna, C., 2011. Rural policing in France: the end of genuine community policing, in: Mawby, R., Yarwood, R. (Eds.), Rural Policing and policing the rural: a constable countryside? Ashgate, Farnham, pp. 45 - 56.

Murdoch, J., 2000. Networks - a new paradigm of rural development? Journal of Rural Studies (16), 407-419.

Murdoch, J., 2006. Networking rurality: emergent complexity in the countryside, in: Cloke, P., Marsden, T., Mooney, P. (Eds.), The Handbook of Rural Studie. Sage, London, pp. 171-184.

Paasche, T.F., Yarwood, R., Sidaway, J.D., 2013. Territorial Tactics: The Sociospatial Significance of Private Policing Strategies in Cape Town. Urban Studies.

Panelli, R., Little, J., Kraak, A., 2002. Rural Women's Experience of Safety, Crime and Fear. University of Otago, Otago.

Parr, H., Fyfe, N., 2013. Missing geographies. Progress in Human Geography (37), 615-638.

Power, E., 2008. Furry families: making a human-dog family through home. Social \& Cultural Geography (9), 535-555. 
Power, E.R., 2012. Domestication and the dog: embodying home. Area (44), 371378.

Samara, T.R., 2010. Policing Development: Urban Renewal as Neo-liberal Security Strategy. Urban Studies (47), 197-214.

Sellick, J., Yarwood, R., 2013. Placing Livestock in Landscape Studies: Pastures New or Out to Graze? Landscape Research (38), 404-420.

Small, I., 2001. Rural Safety Initiative. . West Mercia Police, Worcester.

Smith, R., 2010. Policing the changing landscape of rural crime: a case study from Scotland. International Journal of Police Science \& Management (12), 373-387.

Staeheli, L., 2008. Citizenship and the problem of community. Political Geography (27), 5-21.

Thurman, Q., McGarrell, E., 2005. Community policing in a rural setting Anderson, Cincinnati.

Tuan, Y.F., 1984. Dominance and Affection: The Making of Pets. Yale University Press New Haven.

Urbanik, J., 2012. Placing Animals: An Introduction to the Geography of HumanAnimal Relations. Rowman and Littlefield, Lanham, MD:.

Urbanik, J., Morgan, M., 2013. A tale of tails: The place of dog parks in the urban imaginary. Geoforum (44), 292-302.

Vanderbeck, R.M., 2003. Youth, racism, and place in the Tony Martin affair. Antipode (35), 363-384.

Websdale, N., Johnson, B., 1997. The policing of domestic violence in rural and urban areas: The voices of battered women in Kentucky. Policing and Society (6), 297-317. 
Whatmore, S., 2002. Hybrid Geographies Sage, London.

Woods, M., 1998. Researching rural conflicts: hunting, local politics and actornetworks. Journal of Rural Studies (14), 321-340.

Woods, M., 2006. Political articulation: the modalities of new critical politics of rural citizenship in: Cloke, P., Mardsen, T., Mooney, P. (Eds.), The handbook of rural studies. Sage, London.

Yarwood, R., 2005. Crime concern and policing the countryside: evidence from parish councillors in West Mercia Constabulary, England. Policing and Society (15), 63-82.

Yarwood, R., 2007a. Getting just deserts? Policing, governance and rurality in Western Australia. Geoforum (38), 339-352.

Yarwood, R., 2007b. The Geographies of Policing. Progress in Human Geography (31), 447-466.

Yarwood, R., 2008. Policing policy and policy policing: directions in rural policing under New Labour, in: Woods, M. (Ed.), New Labour's Countryside. Policy Press, Bristol, pp. 205-220.

Yarwood, R., 2010a. An exclusive countryside? Crime concern, social exclusion and community policing in two English villages. Policing \& Society (20), 61-78.

Yarwood, R., 2010b. Risk, rescue and emergency services: The changing spatialities of Mountain Rescue Teams in England and Wales. Geoforum (41), 257-270.

Yarwood, R., 2011a. Voluntary sector geographies, intraorganisational difference, and the professionalisation of volunteering: a study of land search and rescue organisations in New Zealand. Environment and Planning C: Government and Policy (29), 457-472. 
Yarwood, R., 2011b. Whose blue line is it anyway? Community policing and partnership working in: Mawby, R., Yarwood, R. (Eds.), Rural Policing and Policing the Rural: A Constable Countryside. Ashgate, Farnham, pp. 93-108.

Yarwood, R., 2012. One moor night: emergencies, training and rural space. Area (44), 22-28.

Yarwood, R., 2014. Citizenship. Routledge, London.

Yarwood, R., Edwards, B., 1995. Voluntary action in rural areas: The case of neighbourhood watch. Journal of Rural Studies (11), 447-459.

Yarwood, R., Gardner, G., 2000. Fear of crime, cultural threat and the countryside. Area (32), 403-411.

Young, M., 1993. In the Sticks: Cultural Identity in a Rural Police Force. Clarendon Press, Oxford. 